\title{
TECHNOLOGIZATION OF HUMAN OF THE POSTMODERN AGE AS A CHALLENGE TO THE NATURAL REALITY OF THE EARTH
}

\author{
Svitlana Pylypenko ${ }^{l}$ \\ ${ }^{1}$ Department of Philosophy, G. S. Skovoroda Kharkiv National Pedagogical, Kharkiv, Ukraine \\ pilipenkosvetl@gmail.com \\ https://orcid.org/0000-0002-5949-0134
}

ARTICLE INFO

Article history:

Received date 11.05.2021

Accepted date 15.06.202

Published date 30.06 .2021

Section:

Philosophical aspects of the implementation of innovative technologies

DO I

$10.21303 / 2313-8416.2021 .001927$

KEYWORDS

technologization

technology

man

Homo Technologicus

Earth

ecology

Ethics of the Earth

\section{ABSTRACT}

Object of research: technology as a component of human social life in the context of the postmodern era.

Investigated problem: determination of the features of the influence of technological processes on a person of the postmodern era, as a result of which the natural is replaced by an artificial one and the images of both man and the Earth change.

Main scientific results: the study of the contradictions of the process of technologization in the postmodern era made it possible to determine the transformation processes taking place in the life of a person and society. This defines social reality, represented by various markers, among which technology is gaining in importance. The latter act as a composite, which provides new opportunities for determining the relationship between the elements of the "world - man culture" system. It is not only about the emergence of new human figures, among which the technological man (Homo Technologicus) occupies a prominent place, but also the emergence of a new image of the Earth, where the natural is replaced by the technological.

The scope of practical use of the research results: the research results can be used in teaching normative courses "Philosophical Anthropology", "Ethics", "Sociology" for students and undergraduates, graduate students of humanitarian and natural faculties.

Innovative technological product: the plurality of existing technologies (economic, medical, educational, humanitarian, etc.) destroys the new European concept of culture and man, which were provided within the framework of the monoparadigm. The anthropological dimension of technology testifies that the latter are beginning to act as a condition for human expansion. This situation has a significant impact on the existentials of human existence.

The scope of using the innovative technological product: the intensive technologization of the last decades not only provokes environmental risks and changes the state of the Earth, the natural reality of the Earth is replaced by an artificial one, which allows to conclude that the Earth is formed by a technological one.

(c) The Author(s) 2021. This is an open access article under the Creative Commons CC BY license

\section{Introduction}

\section{1. The object of research}

The object of research is technology as a component of human social life in the context of the postmodern era.

\section{2. Problem statement}

The relevance of this topic is due to the fact that none of the previous eras has undergone such triumphs and such catastrophes that marked the twentieth century, having significantly influenced humans and the environment. Human life unfolds in a technogenic civilization, determines the socio-cultural processes of the 21 st century community. So, at the beginning of the twentieth century, H. Ortega y Gasset emphasized that the sensory-creating condition of a person's life is its implementation of the project of being, it can't be conceived without rooting the person itself in it [1]. The problem of human life in being arises, which is increasingly acquiring a technological configuration, exerting significant pressure on a person, as a result of which the latter gradually loses its sense of distance between natural and artificial, nature/Earth and technological space, between itself and the technological world created by it. This situation is demonstrated by such concepts as "post-industrial society, "technological society", "information society", "knowledge 
society", "media society", etc. The value of technology is reinforced by such human figures as" man-nomads "(J. Deleuze , F. Gwattari), "man, who clicks/Homo Zapping” [2], "man, emigrated on the Internet/man-surfer" (J. Deleuze) [3], "man-cyborg" (K. Hazl) [4 ], "Technological man like Homo Deus" [5], etc. At the same time, culture, which is a matrix where a person searches for patterns of interaction, acts as a virtual culture, network culture, technological culture, screen culture, etc., which indicates the multiple configuration of the latter. This allows to conclude that the system "world - man - culture" has undergone significant transformations caused by such a variable as technology.

\section{3. Suggested solution to the problem}

In the humanitarian discourse of the beginning of the XXI century, there has been a significant methodological shift in the definition of technology. Technologies no longer act exclusively as a process or organization of this process, but are understood as a phenomenon, a phenomenon of social life. This allows to assert the importance of using a polyparadigm approach to the definition of technologies, overcomes the limitations in understanding them exclusively in the context of material production. In philosophical writings, the term "replacement technology" is being introduced. So, according to A. Shklyarik, "technology is a general term for the definition of high-tech processes:

1) change non-ecological production methods;

2) use new resources due to scientific discoveries;

3) simulate new space-time conditions;

4) change the capabilities, status and lifestyle of a person through biotechnology, prosthetics and robotization;

5) have relative autonomy;

6) create new spheres of reality - informational or virtual "[6].

Human life/being is associated with technology in cultural, existential, historical, dimensions. Manufacturability arises as a characteristic of a person. Among Ukrainian researchers, certain aspects of this topic are contained in the studies of M. Beilin, L. Gaznyuk, A. Gomilko, A. Sobol and others. Among foreign scientists, one should name M. Castells, S. Lesha, E. Toynbee, F. Fukuyama, K. Schwab, whose works acquired paradigm significance for understanding the processes of the late XX - early XXI centuries.

This situation is definitely related to the technological revolution that took place in the second half of the twentieth century. We are talking about the "Third Wave", which, according to E. Toffler [7], completes the Agrarian and Industrial Revolutions (First and Second waves, respectively). Let's note that K. Schwab [8] emphasizes that the present testifies to the beginning of the Fourth Industrial Revolution, which can be regarded as the "Fourth Wave" in the sense of E. Toffler's reflections.

Thus, F. Fukuyama turns to the analysis of a technological society and defines its following features: first, information is the dominant factor for both human existence and the functioning of technologies; secondly, there is a replacement of physical labor with intellectual; thirdly, under the influence of information and means of communication, a transnational space is being formed; fourthly, these processes are of a global nature and testify to the "Great Gap", which is represented by changes in moral values, not only in social relations, but also in economics, politics and the like. All this articulates a new maxim of the technologized world "There is no between" [9], which allows to say that significant shifts are taking place in a person's self-awareness of itself.

The aim of the study is to determine the specificity of the impact of technological processes on a person of the postmodern era, which causes not only a plurality of images of the latter, but also replaces the natural with the artificial, thereby changing the face of the Earth.

\section{Materials and methods}

The watershed of the XX-XXI centuries provided a person with new technological capabilities, which should include a shift in emphasis from the production of technology to the development and implementation of technologies and technological processes. There is a realization that technologies are connected with the deep meanings of human existence. This situation gives rise to a paradox: a person, using the latest technologies, no longer feels that it is faced with something 
distant or alien, on the contrary, it sees in them something close and understandable. This violates the orientation of a person in the world - it removes the border, for a long time it allowed maintaining a balance between the natural and the artificial, as a result of which the balance between the humanitarian culture and the technological culture is disturbed. It should be emphasized that each of them not only creates its own world, but also articulates various sensor-creative markers. Thus, one of such markers of technological culture is the emergence of the concept of "human-machine complex/human-cyborg", which changes the concept of good and evil, rationality and irrationality, love and hate, etc. interactions lose their historical rootedness, arise fluid, flexible, variable.

This situation has led to the absolute dominance of technologization, which occupies a prominent place in human life and indicates an increase in the technological development of mankind in the XXI century. The features of the latter are the all-round computerization of society, the introduction of biotechnology and genetic engineering, closed production cycles, the phenomenon of robotics, and the like. All this opens up unprecedented possibilities of transformation of man, nature, and the Earth: "Genes can be left intact and watch how they move, or they can be modified and even deliberately damaged in order to see what happens and find out their natural functions. This is called genetic engineering. It is based on the fact that the source of the biological code is universal - all organisms on Earth constitute one huge entity and originate from one evolutionary tree, which, according to Darwinian theory of natural selection, arose and flourished about 4 billion years ago "[10]. However, the introduction of the latest technologies generates contradictions between the co-existence of man and nature/Earth, as a result of which both ecological and anthropological risks of their further existence arise.

According to T. Yashchuk [11], researchers should talk about the era of natotechnology, which takes place at the beginning of the twentieth century, replacing the technology of the post-industrial era of the middle of the twentieth century and producing the era of metacognitive technologies, which, according to the Ukrainian researcher, will begin in the middle of the 21st century. Note that this model is built in the coordinates of the system "technology - economy", however, it requires the addition of one more component - the concept of "man", corresponds to the paradigm of post-nonclassical science, where one of the main principles arises of the principle of human peace. This articulates the problem of human interaction with new technological systems, which should embody the requirements of society for their openness in the context of the problem of a responsible human attitude to technology.

If the thinkers of the early twentieth century were concerned about the growing disagreement between the humanitarian and technological modes of culture, then at the beginning of the XXI century talks about a new symbiosis of ethics and technology, which is associated with a change in the configuration of the culture itself. The latter, being a multidimensional system in the conditions of informatization and technologization of the postmodern society (virtual, informational, screen, technological, etc.), downplayed the imbalance between technological and ethical progress, proposing an updated mythologem of power - the power of man over its own being, proclaiming the cult of the body and the mask, as -from the technology of love, the technology of improving the body, the technology of enrichment, the technology of improving life. This symbiosis has not only greatly simplified the view of human nature, which now closely interacts with technology (in fact, technologies arise as a continuation of man), it is about replacing the technology of "taking care of the Earth" with new ideas for saving humanity like colonizing another "home": "If our discoveries destabilize the ecosystem and threaten humanity, we must discover something that will protect us"[5].

Technologies create their own maps of human activity and testify to both significant transformations of the Earth's landscape and the enhancement of human power, which can serve as a symbol of technological man. There is a transformation of both nature/Earth and man. This situation articulates the question: "Are there places on the planet that are not captured by human attention with the help of technology?" The Earth's landscape is increasingly acquiring a visual gestalt created by artificial satellites, such as a map of megacities or roads, electrification or natural deposits; it no longer represents natural phenomena, but technological achievements of mankind.

A technological person, more and more appears as an "inhabitant of the Earth without a homeland, [and therefore] loses the continuity of traditions" [12], is gradually "forgotten" in a technologized world full of environmental crises. However, it is a person who, so far, is the only 
creature capable of overcoming existing problems by rethinking the meaning and essence of technology. In the first half of the twentieth century, M. Heidegger noted the problem of humanization of technology. Let's note that almost a century has passed, but this problem has not been resolved, on the contrary, it is acquiring new dimensions, as evidenced by environmental crises, the solution of which is a condition for preserving the existence of the Earth for future generations.

The danger is that there has been a shift in emphasis on the use of technology. A person, realizing its own power, continues to live only one day, "here and now," deciding that it can relate to the Earth in terms of its own utilitarian whims like the following thought: oil and gas will flow from them "[13]. This attitude, terrifying in its cynicism, is a symbol of utilitarianism and testifies to the praise of modern European anthropocentric appeals.

The process of transformation of the Earth, as the identification of the results of human activity, resonates with the concept of the "Anthropocene era", which was first applied in 2000 [14], in a certain way "displacing" the concept of "noosphere" by V. Vernadsky. The era of the Anthropocene with the spread of the latest technologies increases the risks of the destruction of the Earth: "In fact, the Earth is a very fragile place of residence, burdened with threats, a small stone that moves at a breakneck speed through the space of the universe" [15]. More and more scientists are noticing the vulnerability of the Earth, so the latter requires special treatment. A kind of manifesto of these reflections is the principle that a person has the right to the Earth only for intelligent life, which resonates with the paradigm of a caring attitude of a person to the Earth as a subject of existing interactions.

\section{Research results and discussion}

Technology (in its broad sense) is one of the most important factors of the postmodern era, which determines the development of all spheres of culture and society as a whole - from art and mass communications to business and politics. It acts as a special type of information and communication, produces communication tools that allow a person to connect to completely alien worlds for it. Technology overcomes time and space, overcomes distance. With the help of the latest technology, a person can be present online, while being away from a certain place. As a result, the impossible becomes embodied. The emergence of technological culture in the life of society is the result of the indisputable fact that technology is becoming a rather powerful tool for influencing the surrounding world. Now a person needs to understand and define the boundaries of its being, to identify a new question - the question of the purposeful all-round development of itself as a person in the process of communication with technology. Such a concept is comprehensively considered by the scientific community, both philosophical and representatives of technical knowledge. Researchers note that Homo Technologicus acts as a demiurge in relation to itself.

Humanity "fell in love" with technologies, which at the beginning appeared as its favorite toy, but the question arises: "has human life become safer?". "Today we are trying to design an 'internet for everything', hoping that it will make us healthy, happy and strong. However, only the "Internet for everything" will be built and put into operation, people can be reduced from engineers to chips, and then to data, and in the end it is possible to dissolve in a rushing stream of data, like a clod of earth in a turbulent river. ... Those templates that we ourselves came up with will doom us to oblivion together with mammoths and Chinese river dolphins. Looking back, humanity will discover that it is only Brijachams in the cosmic stream of data" [5]. Technologies arise as an obligatory attribute of human life and society, awakening subconscious aspirations, redirecting desire and hope, experiences and social practices. Let's note that technologies are so interconnected with each other, in fact, initiate their constant improvement and emergence, thereby provoking a kind of "mix of nature."

In the XXI century, it became clear that science merged with technology, technology and man, which led to the emergence of a new phenomenon, which appeared as man-measuring technology. Technology frees man from nature and, accordingly, from the Earth, as a result of which man stands as an unrooted being, dependent on new systems, already created by technology. For Homo Technologicus [16], its own adaptability arises as a characteristic of its life-creation. This is transforming the very phenomenon of technology. The latter are no longer exclusively the result of human creative activity, they produce themselves, arise as an independent phenomenon, retain their meaning even outside the sphere of human life. The possible consequences of this situation 
are of increasing concern to scientists. So, one of the extreme forms of manifestation of the transformation of the Earth as a result of technologization can be the following configuration of the Earth: "In one popular scenario, a corporation is shown, develops the first artificial intelligence and asks it a certain test - to calculate the number $\pi$. Until at least someone begins to understand what is happening, artificial intelligence takes over the entire planet, destroys the human race, begins a campaign to capture the rest of the galaxy and turns the entire known universe into a giant supercomputer, billions upon billions of years calculates $\pi$ even more accurately. In the end, this is a heavenly mission entrusted to it by the Creator" [17]. From now on, not only a person acts as the creator of life and being, but also the results of its actions/the consequences of technologies form its "I"; a person becomes a derivative, dependent on the technologies that were created by it.

Thanks to technology, many problems are eliminated, but the person itself is also eliminated. So, T. M. Alexander notes that in order to resolve this contradiction, nature should be "invoked" and this can be accomplished by addressing the problem of being, however, this follows from the being of natural, which will make it possible to realize the depth and breadth of the co-existence of man and nature/land, not man and technology [18].

The transformation of the Earth is taking place, more and more it acquires a technological configuration, where agricultural skills are gradually pushed aside by the ability to find the necessary information. Therefore, when it comes to "global villages", other communities are identified that are radically different from the usual rural way of life. It is possible to talk about the destruction of the natural reality of the Earth and the provision of it, as well as the actual person, an artificial reality.

One of these problems remains the action of cultivating the land, replaced by technology. The latter, of course, aimed at facilitating human labor, however, they contribute to the strengthening of a person's alienation from the earth, because they represent the latter as an external object relative to the social space of the individual, thereby avoiding the application to it of any markers that can be considered in the sense of the Ethics of the Earth ... The practice of cultivating the land takes the form of a kind of conveyor, where a person only has the right to press buttons (Push-buttons). The figure of a man-farmer or "man from the Earth" is replaced by a "technician" whose main task is to support continuous work to meet economic needs. The earth, with life-giving force, turns into an object that must be used, hoping for it, if not forever, then a long-term existence.

Despite the fact that the study focused on defining the features of technologization of a person in the postmodern era, it should be emphasized that the formation of a new technological paradigm of the XXI century within the framework of post-non-classical philosophy, it expands the existing methodological tools and allows to attract the optics of natural sciences. The inclusion of the latter, in our opinion, will strengthen the interdisciplinary discourse and define new perspectives for solving the articulated problem. In the future, it is planned to study the paradoxes that arise in man's attitude to the Earth, in connection with the formation of the paradigm of space colonization for the purpose of tourism (I. Musk), which may indicate the beginning of the post-postmodern era (S. Lesch).

\section{Conclusions}

Innovative technologies in all spheres of life and life creation of a person of the postmodern era produce not only the desired future, but also determine the problems associated with human existence at the turn of the millennia, which reached the planetary level, forcing to rethink the boundaries of the existence of both humanity and the planet as a whole. This allows to conclude that humanity is the XXI century is a witness of the approach of a new "axial time", will embody a new attractor and determine the further vector of human technological development. The technologization of man gives it new opportunities to improve the environment, the consequences of which can finally destroy the connection between man and the Earth. One of the main problems is providing the Earth with an artificial configuration, which leads to the displacement of its natural reality. In this regard, the problem of a person's responsible attitude to technology in the context of preserving moral meaning is of particular importance; technology should not contradict humanity. This also applies to the conservation of the Earth, must be embodied by the Ethics of the Earth in order to overcome the negative consequences of the technologization of the latter. 


\section{References}

[1] Ortega-i-Gasset, Kh. (1997). Vokrug Galileya (skhema krizisov). Izbrannye trudy. Moscow: Ves mir, $233-403$.

[2] Shutiak, L. (2010). Transformatsiia kontseptualnoi svitomodeli homo legens u homo zapping. Pytannia literaturoznavstva, 80 , 170-174.

[3] Deleuze, G. (1992). Postscript on the Societies of Control. October, 59 (Winter), 3-7.

[4] Kheilz, K. N. (2013). Yak my staly postliudstvom: Virtualni tila v kibernetytsi, literaturi, informatytsi. Kyiv: Nika-Tsentr, 426.

[5] Kharari, Yu. N. (2018). Homo Deus. Liudyna bozhestvenna. Za lashtunkamy maibutnoho. Kyiv, 512.

[6] Shklyarik, E. N. (210). Novaya ontologiya. Informatsionnaya epokha: vyzovy cheloveku. Moscow: Rossiyskaya politicheskaya entsiklopediya, 230-257.

[7] Toffler, E. (2000). Tretya volna. Kyiv: Vid. Dim «Vsesvit», 480.

[8] Shvab, K. (2019). Chetverta promislova revolyutsiya. Formuyuchi chetvertu promislovu revolyutsiyu. Kharkiv: KSD, 416.

[9] Fukuyama, F. (2004). Nashe postchelovecheskoe buduschee. Posledstviya biotekhnologicheskoy revolyutsii. Moscow: OOO «Izdvo AST», OAO «Maks», 349.

[10] Rezerford, A. (2018). Syntetychna biolohiia. Shcho dali? Vse, shcho nauka znaie pro nashe maibutnie. Kyiv, $79-88$.

[11] Yashchuk, T. (2017). Economy as a subject matter of modern practical philosophy. Filosofska dumka, 3, $24-40$.

[12] Yaspers, K. (1994). Smysl i naznachenie istorii. Moscow: Politizdat, 527.

[13] Kliain, N. (2016). Zminiuietsia vse: Kapitalizm proty klimatu. Kyiv: Nash Format, 480.

[14] Steffen, W., Crutzen, P., Mcneill, J. (2008). The Anthropocene: Are Humans Now Overwhelming the Great Forces of Nature. Ambio, 36 (8), 614-621. doi: http://doi.org/10.1579/0044-7447(2007)36[614:taahno]2.0.co;2

[15] Svensen, H. (2014). Kinets svitu blyzko: Pro stykhiini lykha ta yikh vplyv na suspilstvo. Lviv: Kalvariia; Kyiv: Nika-Tsentr, 248.

[16] Warwick, K. (2016). Homo Technologicus: Threat or Opportunity? Philosophies, 1 (3), 199-208. doi: http://doi.org/10.3390/ philosophies1030199

[17] Kristian, D. (2019). Velyka istoriia vsoho. Kyiv: Nash format, 336.

[18] Alexander, T. M. (2016). The Voices of Nature: Toward a Polyphonic Conception of Philosophy. Telos, 177, 145-167. doi: http:// doi.org/10.3817/1216177145 